\title{
From Plastic to Fuel - New Challenges
}

\author{
MARIUS CONSTANTINESCU ${ }^{1,2}$, FELICIA BUCURA ${ }^{1}$, EUSEBIU ILARIAN IONETE ${ }^{1}$, DANIELA ION-EBRASU ${ }^{1}$, \\ CLAUDIA SANDRU ${ }^{1}$, ANCA ZAHARIOIU ${ }^{1,2}$, FLORIAN MARIN ${ }^{1}$, MARIUS GHEORGHE MIRICIOIU ${ }^{1,3 *}$, \\ VIOLETA CAROLINA NICULESCU ${ }^{1}$, SIMONA OANCEA ${ }^{2}$, ROXANA ELENA IONETE ${ }^{1 *}$ \\ ${ }^{1}$ Research Department - ICSI Analytics, National Research and Development Institute for Cryogenics and Isotopic Technologies - ICSI Rm. Valcea, \\ 4 Uzinei Str., 240050, Râmnicu Vâlcea, Romania \\ ${ }^{2}$,Lucian Blaga University of Sibiu, Faculty of Agricultural Sciences, Food Industry and Environmental Protection, 7-9 I. Ratiu Str., 550012 Sibiu, Romania \\ ${ }^{3}$ Politehnica University of Bucharest, Faculty of Applied Chemistry and Materials Science, 1-7 Polizu Str., 011061 Bucharest, Romania
}

The increased demand for energy sources is the driving force to convert organic compounds into alternative fuels. Plastic waste disposal affects the environment, since they are not easily recycled and, during the recycling process, they can produce waste ash, heavy metals, or potentially harmful gas emissions. In the plant design for plastic converting into fuel, the chemical reactor is one of the advanced equipment in the field of chemical and process engineering. This study emphasizes the feasibility of pyrolysis process for valorisation plastics by producing energy-efficient products. In this respect, samples of polypropylene, polyethylene and polystyrene were used as models and subjected to pyrolysis processes at $450{ }^{\circ} \mathrm{C}$, in the presence of two types of mesoporous silica materials, MCM-41 and SBA-15, using a modern developed reactor. The use of mesoporous materials increased the calorific value of the obtained oil and gas, thus improving the economic potential of the process end products. This study dealt with the extraction of oil from plastics termed as plastic pyrolysis oil (PPO) and plastics pyrolysis gas (PPG), with a composition rich in different types of hydrocarbons and they can be marketed at much cheaper rates compared to that present in the market.

Keywords: alternative fuels, mesoporous silica, plastic waste, pyrolysis, recycling

The European Environment Agency (EEA) drew attention to the necessity of reducing pollution by an effective waste management. In this context, an important EU project "Ocean Clean-up" estimated at over 40 million euro has been developed since September 2018, the project aiming to reduce the amount of plastic in the world's oceans by at least $90 \%$ by 2040 [1]. Wastes could be recovered using a special giant mesh, and further recycled in different ways. Finding feasible solutions for removing plastic wastes through energy recovery can be a major step in reducing the $\mathrm{CO}_{2}$ footprint.

The problem of plastic wastes is common also in highly developed countries of North America, EU, and in Asia. The need for research of waste disposal by recycling plastic wastes is due to their high naturally decomposition time period, thousands of years. There are some well-known pathways for plastic wastes recycling and reintroduction into the industrial cycle, but the feasible option of disposal through energy recovery seems an effective alternative [2]. The energy recovery from wastes, including plastics, or the design and concept of energy systems based on renewable sources [3,4], would represent modern ways of efficient fossil fuel consumption, preservation and resources sustainability for Romania. Pyrolysis is an irreversible process of chemically decomposition of organic materials at high temperatures, in the absence of oxygen. It is commonly used to convert organic materials into liquid, gas and solid residues. Recent research works have been focused on the possibility of polystyrene wastes disposal through energetic gain, without using catalysts, by pyrolysis at different temperatures [5]. Another experiment was based on low- and high-density polyethylene (LDPE and HDPE) and polypropylene (PP) converted into liquid fuel by slow pyrolysis at low temperatures (from $300{ }^{\circ} \mathrm{C}$ to $400{ }^{\circ} \mathrm{C}$ ), long isothermal holding time, in a semi-batch reactor [6].

The pyrolysis for obtaining useful chemical products is the opposite of the Fischer-Tropsh process, where carbonaceous material (coal) is first combusted in order to give syngas. Then, the syngas is transformed into targeted higher molecular chain hydrocarbons (diesel or paraffin). By contrary, the pyrolysis begins with higher molecular chain hydrocarbons and then crack them using heat, catalyst or hydrogen gas [7, 8], obtaining smaller chain hydrocarbons, such as liquid fuels. Pyrolysis is basically a thermal degradation, being important to understand the effect of mixing feed material with different melting points. The other factors that must be taken into consideration for evaluating the process efficiency are the type of reactor, temperature, pressure, residence time or cooling step [9].

The progress of a pyrolysis process involving catalysts, such as mesoporous materials has been also the subject of several studies on plastic wastes, PE and PP [10]. The effect of different temperatures and holding time on the pyrolysis products (liquid, char, and gas) were studied on HDPE wastes, in a batch reactor over a range temperature of $400{ }^{\circ} \mathrm{C}-550{ }^{\circ} \mathrm{C}$ [11]. Pyrolysis accompanied by several types of zeolites, ZSM-5, mordenite, pellets and powder, could generate liquid and gaseous fuels at the end of the process, as shown by a study on plastic wastes samples rich in PE and PP [12]. The results showed that using zeolites in the pyrolysis process, the composition of the obtained fuels is calorifically enriched. A study on disposal of some polyethylene wastes highlighted the combination of a fixed bed reactor and catalysts (zeolites) as an effective solution

*email: marius.miricioiu@icsi.ro; roxana.ionete@isci.ro 
for increasing the quality of hydrocarbons [13]. Polypropylene, an important polymer with numerous industrial applications, was pyrolyzed in the absence or presence of a natural zeolite (NZ) [14]. The quantity and quality (calorific value) of the liquid obtained from the catalytic pyrolysis (rich in hydrocarbons) was found to be much higher than those in the absence of the catalyst.

Therefore, in this study was investigated the thermochemical effect, the basis of a pyrolysis process, applied to several types of polymeric materials, the polyethylene (PE), polypropylene (PP) and polystyrene (PS), responsible for more than 90 $\%$ of plastic products and wastes in Romania.

As a further step in our research related to the disposal by valorisation of specific wastes $[15,16]$, this study aimed to investigate the thermochemical effect, the basis of a pyrolysis process, applied to several types of polymeric materials, the polyethylene (PE - HDPE and LDPE), polypropylene (PP) and polystyrene (PS), responsible for more than 90\% of plastic products and wastes in Romania. Thus, we assessed the pyrolysis of plastics both in the absence and presence of a mesoporous silica material, trying to obtain feasible data for designing and implementing a sustainable process for recycling of plastic waste. Our results, demonstrated the feasibility of the process by producing a measurable quantity of pyrolysis oil that can be further upgraded into its separate fuel fractions. This technology can solve the plastic wastes disposal problems in the community and, also, it can drive to products with economic value.

\section{Experimental part}

Materials, methods and apparatus

The plastic materials were purchased from Adiran Petrochemicals (Bucharest, Romania) and used in the investigation as received: polyethylene (PE, HDPE and LDPE), polypropylene (PP) and polystyrene (PS). Pure plastic materials were used in this stage of investigation to better design the reactor and monitor the pyrolysis process, possible to be further extended for plastic waste.

The mesoporous silica MCM-41 and SBA-15 were prepared according to previously developed methods [17-19]. They were used as catalysts in the catalytic pyrolysis tests displaced within a metallic mesh system (304L stainless steel) with the following properties: eye length of $0.24 \mathrm{~mm}$, eye width $0.071 \mathrm{~mm}$, wire size $0.16 \mathrm{~mm} \pm 0.002$, width $750 \mathrm{~mm}$ and diameter $0.16 \mathrm{~mm}$.

The plastic materials were characterized by ATR-FTIR in the domain of 650-4,000 $\mathrm{cm}^{-1}$ with $4 \mathrm{~cm}^{-1}$ resolution, by using a CARY 630 FT-IR spectrometer (Agilent Technologies, Santa Clara, CA, USA) [20, 21]. Thermogravimetric analysis (TGA) was carried out using a TGA-DSC (NETZCH STA, Jupiter, USA) in the temperature range of $25^{\circ} \mathrm{C}-700{ }^{\circ} \mathrm{C}$ at a heating rate of $10{ }^{\circ} \mathrm{C} \mathrm{min}{ }^{-1}$ under nitrogen flow $[22,23]$.

Compositional characterization of the oils obtained in the pyrolysis processes was achieved using an elemental analyser, Flash EA 2000 (Thermo Scientific, UK). PPO samples were introduced into special tungsten - silver nacelles, subjected to combustion-pyrolysis at extremely high temperatures of $950{ }^{\circ} \mathrm{C}-1050{ }^{\circ} \mathrm{C}$; the resulting gases $\left(\mathrm{CO}_{2}, \mathrm{NO}_{2}, \mathrm{SO}_{2}, \mathrm{H}_{2} \mathrm{O}, \mathrm{CO}\right)$ passed a quartz reactor with a special filler, then the gas chromatographic columns with SM5A - Porapak Q filler, and detected by a thermal conductivity detector-TCD [24]. Calibration of the elemental analyser was performed with 2.0-3.0 mg of BBOT (C: 72.58 wt.\%, H: 6.09 wt.\%, S: 7.43 wt.\%, O: 7.41 wt.\% and N: 6.54 wt.\%), an amino acid traceable to NIST.

The content of heavy metals ( $\mathrm{As}, \mathrm{Cd}, \mathrm{Co}, \mathrm{Cr}, \mathrm{Hg}, \mathrm{Mn}, \mathrm{Ni}, \mathrm{Pb}, \mathrm{Rb}, \mathrm{Se}, \mathrm{Sr}$ ) from the PPO's was performed by flame atomic adsorption spectroscopy using a NOVAA300 AAS (Analytic Jena, Germany). The determination of Cu was made with a graphite furnace atomic adsorption spectrophotometer 650 ZENIT (Analytic Jena, Germany). A multielement standard solution XVICertiPUR (a mixture of 21 elements in diluted nitric acid) purchased from Merck (Darmstadt, Germany), with a certified value of $100 \pm 3 \mathrm{mg} / \mathrm{L}$, was used for calibration curve in the quantitative analysis of metals.

Chlorine in the plastic waste samples was determined using an elemental analyser EA 4000 (Analytic Jena, Germany). The equipment uses a special heated reactor made from quartz, at $1000^{\circ} \mathrm{C}$, in a high purity $\mathrm{O}_{2}(99.999 \mathrm{Vol} \%)$ atmosphere.

A C5000 calorimeter (IKA, Germany), using a combustion method, was chosen to generate information about the PPO's energy value [25]. The quantity of PPO's, used in the oxygen bomb was $\sim 0.2 \mathrm{~g}$. To validate the results, an RSD $<0.5 \%$ was considered appropriate for triplicate measurements. The hydrocarbons content of the PPO's samples was determined using the gas chromatographic technique in tandem with mass spectrometry GC-MS [26].

The qualitative and quantitative composition, permanently gases, water and hydrocarbons, of PPG's, was performed using a GC (CP 3800 Varian Inc., USA) equipped with two detectors, TCD and FID type, capillary columns with type fillings like SM5A, PoraPLOT Q and $\mathrm{Al}_{2} \mathrm{O}_{3} / \mathrm{KCl}$ [27-29]. The calibration of the methods developed for these investigations was done in three points, with a linearity of $\mathrm{R}^{2}>0.995 \%$.

\section{Experimental part}

The pyrolysis process was performed both in the absence and in the presence of the mesoporous silica. For the experimental tests a fixed-bed refractory steel reactor (Fig. 1) was designed. A sandwich metallic mesh system (SMMS) was used to support the catalysts (MCM-41 or SBA-15) inside the pyrolysis reactor.

The quantity of plastic wastes used in the experiments was around $50 \mathrm{~g}$; the pyrolysis temperature was $450{ }^{\circ} \mathrm{C}$. 


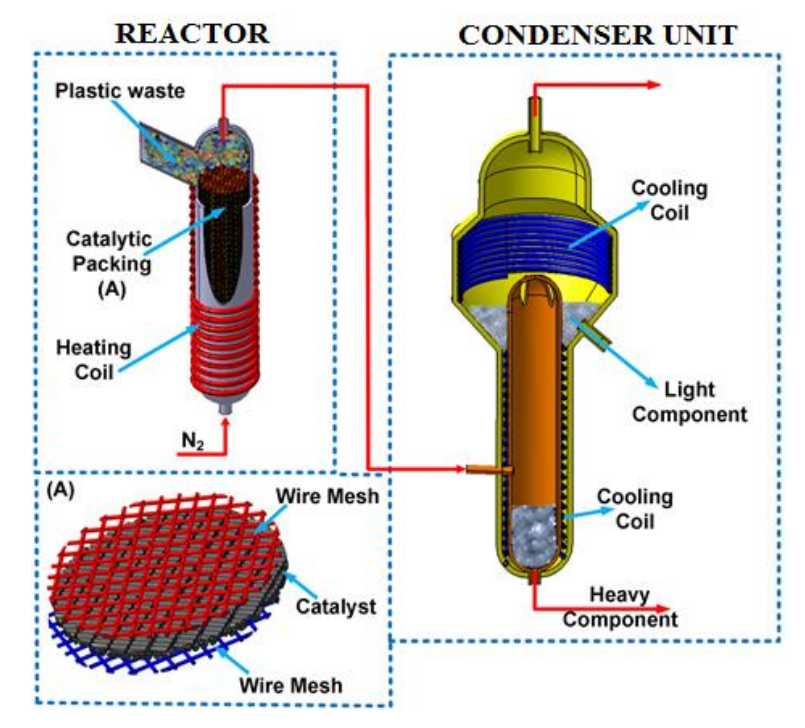

Fig. 1. Main components of the experimental set-up for the pyrolysis of plastics

Complex tests were performed on both oil and gas products derived from the pyrolysis process, in order to determine the influence of process conditions on aromatic and polycyclic hydrocarbons. The resulted pyrolysis/reaction products were: plastics pyrolysis oil (PPO), plastics pyrolysis gas (PPG) and plastics pyrolysis waste/wax (PPW).

The liquid/gas ratio, hydrocarbons composition/evolution depending on the arrangement and the residual level were evaluated at a stable working temperature.

In a previous study [16] we have shown data related with the pyrolysis processes of catalysts directly mixed with plastic wastes. Upon completion of this processes, the catalysts cannot be recovered; they became part of the viscous mass of the residue/wax at the end of the pyrolysis experiments. Installation of the SMMS in the pyrolysis reactor can generate both added value through the generating reactions and generation of hydrocarbons with increased energy value, but also increasing their lifetime. In our present work, the SMMS was arranged in the middle of the reactor so that it can react to the vapours resulted from the process of heating the plastic wastes. The positioning of the sandwich metallic mesh system provided space and time for reactive vapours to penetrate toward the condensation side of the catalysts. The arrangement consisted in two stainless steel meshes, each having $1 \mathrm{~mm}$ thickness, and $1 \mathrm{~mm}$ thick quartz wool in the middle. The catalyst, either MCM-41 or SBA15 , was introduced into the quartz wool, as a powder, of a maximum mass $\sim 10 \mathrm{~g}$.

The PPW installation consisted in a reactor - made from refractory steel with $\mathrm{H}=500 \mathrm{~mm}$; $\mathrm{D}_{\text {int }}=100 \mathrm{~mm}$; isolated with basalt wool, condenser - condensing gas cooling system with $\mathrm{L}=500 \mathrm{~mm}$; cooled with water at $10{ }^{\circ} \mathrm{C}$, glass bottle, Erlenmeyer flask, to collect condensate hydrocarbons, PPO's, 5 L Tedlar bag (CEL Scientific Corporation, USA), for collecting noncondensate gases, PPG's. The reactor was continuously purged with high purity $\mathrm{N}_{2}(99.999 \mathrm{Vol} \%)$ (Linde Gas, Germany), at $\mathrm{Q} \sim 150 \mathrm{~mL} / \mathrm{min}$, in order to create an oxygen-free atmosphere and also as a carrier gas for the created vapours. As the provision of experimental temperatures was secured by heating the refractory steel reactor through the outside, for a good temperature transfer, we considered a steel crucible $\left(H=100 \mathrm{~mm} ; \mathrm{D}_{\text {int }}=95 \mathrm{~mm} ; \mathrm{D}_{\text {ext }}=98 \mathrm{~mm}\right)$, to hold the plastic feed in the lower third of the reactor, with ribs/dents specially created over its entire $360^{\circ}$ circumference and supported on a steel foot, $\mathrm{H}=50 \mathrm{~mm}$. Thus, the nitrogen gas introduced at the bottom of the right side of the reactor can be uniformly passed along the crucibles, being able to easily take hot vapours through the sandwich metallic mesh system (SMMS).

Pyrolysis was performed from the room temperature to a final temperature of $450{ }^{\circ} \mathrm{C}$, with $10{ }^{\circ} \mathrm{C} / \mathrm{min}$ heating rate, being maintained at $450{ }^{\circ} \mathrm{C}$ for 30 minutes to provide complete pyrolysis. SMMS/catalysts, positioned in the middle of the reactor, were heated according to the temperature range of the entire reactor and not individually. Pyrolysis involved degradation of polymeric materials by increasing the controlled temperature in the absence of oxygen. The interest was a pragmatic one, transforming plastic material into PPO and PPG, rich in hydrocarbons, which is equivalent to energy. The structure of this materials is an endless chain of structures $(-\mathrm{C}-\mathrm{H}-\mathrm{)}$, two fuel elements in turn. In the developed reactor, the chemical reactions, such as cracking, depolymerization, isomerization, oligomerization, cyclization, dehydrogenation and aromatization, took place. In the process of polymer chain degradation using catalysts, the molecular weight of the polymer chain was rapidly reduced by the cracking reaction, and then the hydrogen atoms and carbon atoms were rearranged resulting in high-quality isomers. Pyrolysis has carried out the chain breaking process, which is randomly broken down into smaller molecules with different chain lengths [30]. The reactions carried out in the reactor were:

$$
\begin{aligned}
& {\left[\mathrm{CH}_{2}=\mathrm{CH}_{2}\right]_{\mathrm{n}}+\left[\mathrm{CH}_{2}=\mathrm{CH}_{2}-\mathrm{CH}_{3}\right]_{\mathrm{n}} \rightarrow\left[\mathrm{C}_{\mathrm{n}} \mathrm{H}_{2 \mathrm{n}}+2\right]_{\mathrm{n}} \uparrow+\left[\mathrm{C}_{\mathrm{n}} \mathrm{H}_{2 \mathrm{n}}\right] \uparrow} \\
& \mathrm{CH}_{3}-\mathrm{CH}_{2}-\mathrm{CH}_{2}-\mathrm{CH}_{3} \rightarrow \mathrm{CH}_{2}=\mathrm{CH}-\mathrm{CH}_{2}-\mathrm{CH}_{3} \uparrow+\mathrm{H}_{2} \rightarrow \\
& \mathrm{CH}_{3}-\mathrm{CH}=\mathrm{CH}-\mathrm{CH}_{3} \uparrow+\mathrm{H}_{2} \uparrow \\
& 2 \mathrm{CH}_{2}=\mathrm{CH}_{2} \rightarrow \mathrm{CH}_{3}-\mathrm{CH}=\mathrm{CH}-\mathrm{CH}_{3} \uparrow
\end{aligned}
$$


The quantity of products obtained at the end of each pyrolysis experiment, was determined using the following equations:

$$
\begin{aligned}
& \% \mathrm{PPO}=\frac{\mathrm{m}_{\mathrm{PPO}(\mathrm{g})}}{\mathrm{m}_{\text {plasticwaste }(\mathrm{g})}} * 100 \\
& \% \mathrm{wax}=\frac{\mathrm{m}_{\mathrm{wax}(\mathrm{g})}}{\mathrm{m}_{\text {plasticwaste }(\mathrm{g})}} * 100 \\
& \% \mathrm{PPG}=100-(\% \mathrm{PPO}+\% \text { wax })
\end{aligned}
$$

\section{Results and discussions}

Characterization of the plastic materials subjected to pyrolysis

The ATR-FTIR spectra of the polystyrene (PS), polypropylene (PP), high-density polyethylene (HDPE), and low-density polyethylene (LDPE) used as test plastic samples for the experiments, are displayed in Fig. 2.

For the neat polymers, the spectrum showed the typical characteristic bands corresponding to the aliphatic $\mathrm{C}-\mathrm{H}$ and $-\mathrm{CH}_{2}$ and the aromatic $\mathrm{C}=\mathrm{C}$ stretching, respectively. Finally, the peaks in the region $2800-3100 \mathrm{~cm}^{-1}$ correspond to aromatic $\mathrm{C}-\mathrm{H}$ and $=\mathrm{C}-\mathrm{H}$ stretching.
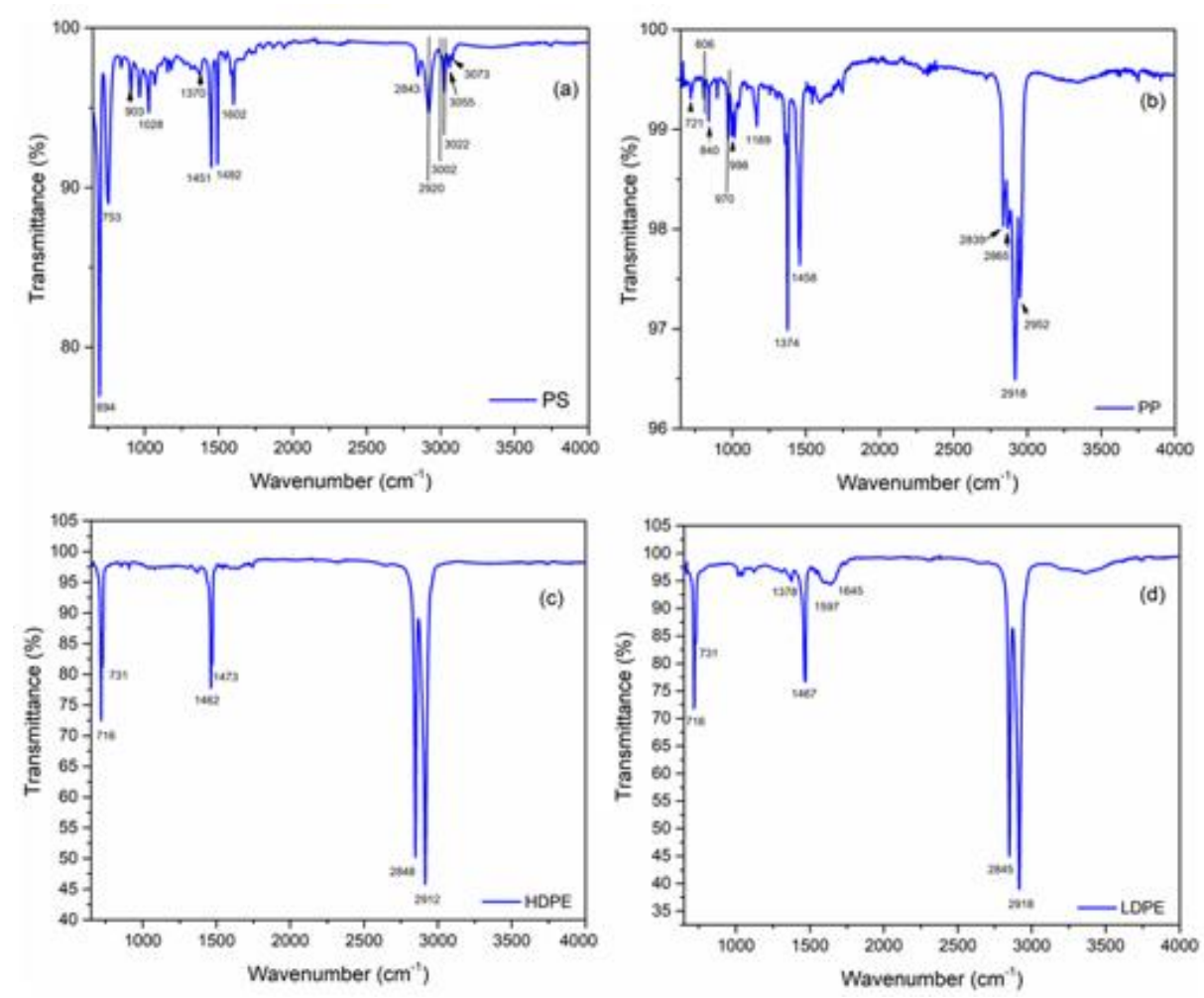

Fig. 2. ATR-FTIR spectra of the commercial polymeric materials: a) PS, b) PP, c) HDPE and d) LDPE

The TG diagrams of the PS displayed two-stage degradation steps, shown in Fig. 3(a). The main loss of $97 \%$, due to the polymer degradation started from $\sim 300{ }^{\circ} \mathrm{C}$ to $456{ }^{\circ} \mathrm{C}$. The small loss of $3 \%$ was probably caused by the decomposition process associated with the thermal degradation of the additive [31]. In the case of PP, it displayed two-stage degradation steps, but compared to PS, the PP first loss started at lower onset temperature at $250{ }^{\circ} \mathrm{C}$ to $380{ }^{\circ} \mathrm{C}$, being caused by the polymer degradation. The $4 \%$ second stage loss may be assigned, as in case of PS, to the polymer tacticity. The higher degradation temperature of PS is caused by the aromatic ring of styrene that increases the thermal resistance in comparison with PP. Degradation characteristics were found similar for HDPE and LDPE, since both have similar polymer backbone [6], although as noticed in Fig. 2 - (c), (d) and (e) the first one is more stable, the first weight loss starting at about $50{ }^{\circ} \mathrm{C}$ later than the last one.

TG measurements highlighted that all the commercial samples were not pure and contained small quantities of additives, as proved by the presence of the second mass loss. Based on the TGA and FTIR measurements, it was concluded that the most suitable temperature for pyrolysis experiments must be $450{ }^{\circ} \mathrm{C}$.

Also, the main characteristics obtained for the used polymers are presented in Table 1. 

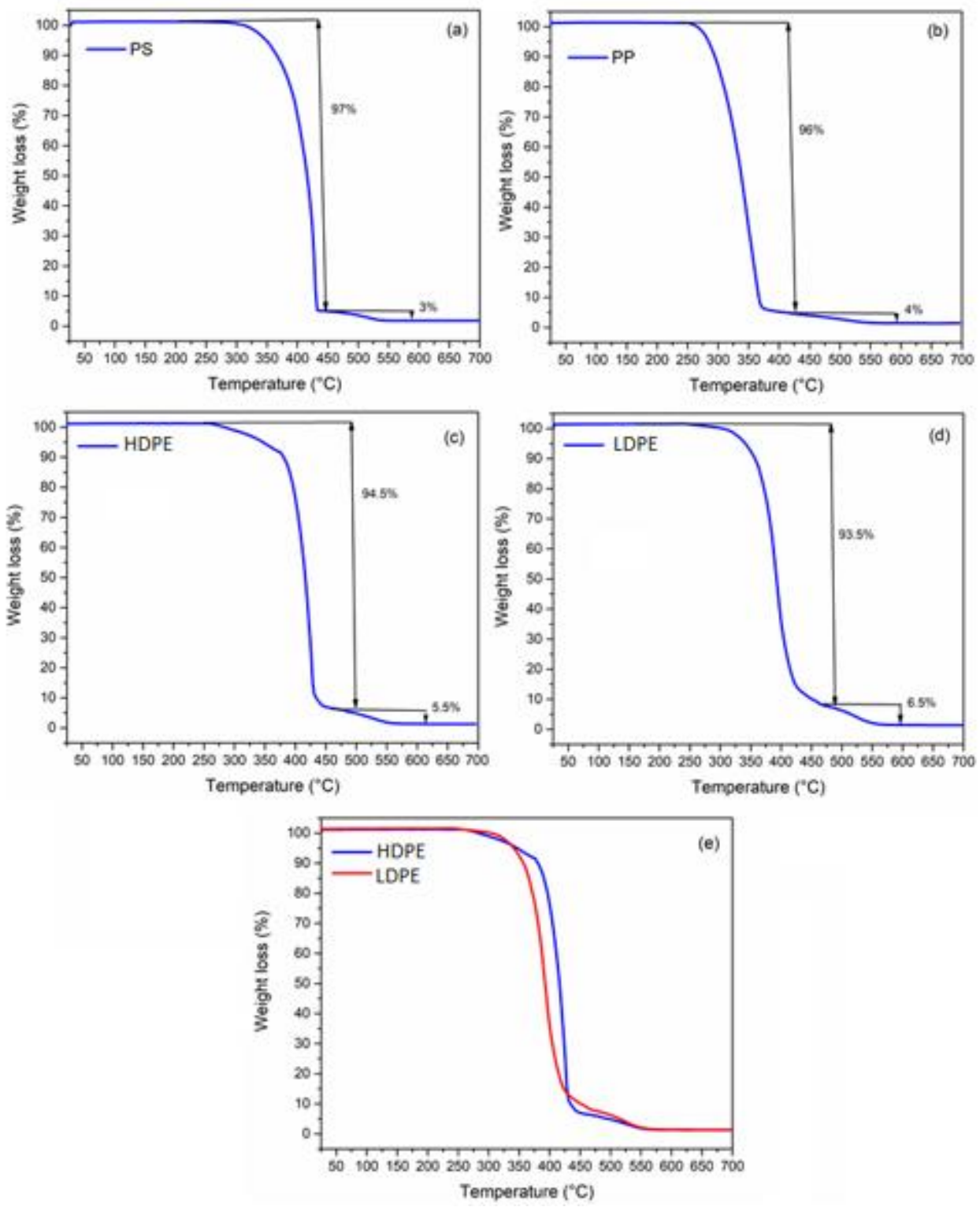

Fig. 3. Thermogravimetric analysis of polymeric materials: a) PS, b) PP, c) HDPE, d) LDPE and e) HDPE / LDPE

Can be observed that the polyethylene materials have higher values of HHV and LHV, sustaining the hypothesis that these polymers can be used in order to produce unconventional fuels.

Characterization of the pyrolysis product - pyrolysis plastics oil (PPO)

In order to compare to the classical liquid fuels, the investigations on the oils obtained from pyrolysis of PP, PE (HDPE and LDPE) and PS primarily focused on the level of heavy metals.

The detected metals (Table 2) are considered to be toxic and known to cause multiple damage to internal organs even at lower exposure levels, while $\mathrm{Se}, \mathrm{Cr}, \mathrm{Mn}, \mathrm{Cu}$ are essential elements and their dose causes the threat. Some metals, such as $\mathrm{Cd}$, $\mathrm{Pb}, \mathrm{Hg}, \mathrm{As}, \mathrm{Rb}, \mathrm{Sr}$, are also classified as human carcinogens according to U.S. Environmental Protection Agency and the International Agency for Cancer Research [32].

There is a fairly high density in heavy metals in the PPOs, but it is natural by tracing the origin of these - polymers - crude oil. It can be observed the low content of metals, regardless the element, compared to any representative fossil liquid fuel [33].

The results regarding the elemental analysis of PPOs which is required for the evaluation of the level of future $\mathrm{NO}_{\mathrm{x}}, \mathrm{SO}_{\mathrm{x}}$, $\mathrm{CO}_{2}$ emissions and of the energy level by determining C-H-O and HHV and LHV are described in Table 3.

The appearance of the obtained PPOs was mainly oily, except for those based on PS, which are viscous. Also, the scent was characteristic for liquid fuels obtained from crude oil (hydrocarbons odour), the only particularity being in the PPOs based on PS, adding an odour of styrene. A slight decrease of the nitrogen level, which can cause nitrogen oxides through the combustion of liquid fuels, was registered for each PPO obtained from catalytic pyrolysis, using mesoporous silica catalysts MCM-41 or SBA-15. Also, the calorific value of PPOs increased in catalytic supported pyrolysis experiments. 
Each catalyst, either MCM-41 or SBA-15 contributed differently, demonstrating its different affinity and capability to improve the progress of processes. The most remarkable impact of catalysts was registered for LDPE, with a very high level of energy after the catalytic pyrolysis. Except for LDPE, SBA-15 determined increased energy levels compared to MCM-41, for the investigated polymers.

Table 1

PROPERTIES AND CHARACTERISTICS OF THE INVESTIGATED POLYMERS

\begin{tabular}{|c|c|c|c|c|c|c|c|c|c|c|c|}
\hline Polymer type & $\begin{array}{l}\text { Density } \\
\mathrm{g} / \mathrm{cm}^{3}\end{array}$ & Melting point ${ }^{\circ} \mathrm{C}$ & $\begin{array}{c}\text { Diameter } \\
\mathrm{mm}\end{array}$ & $\begin{array}{c}\mathrm{N} \\
\text { wt. } \%\end{array}$ & $\begin{array}{c}\mathrm{C} \\
\text { wt. } \%\end{array}$ & $\begin{array}{c}\mathrm{H} \\
\text { wt. } \%\end{array}$ & $\begin{array}{c}\mathrm{S} \\
\text { wt. } \%\end{array}$ & $\begin{array}{c}\mathrm{O} \\
\text { wt. } \%\end{array}$ & $\begin{array}{c}\mathrm{HHV} \\
\mathrm{J} / \mathrm{g}\end{array}$ & $\begin{array}{c}\text { LHV } \\
\mathrm{J} / \mathrm{g}\end{array}$ & $\begin{array}{l}\mathrm{Cl} \\
\mu \mathrm{g}\end{array}$ \\
\hline HDPE & 0.939 & 129 & 2.00 & 0.16 & 86.20 & 9.55 & 0.005 & 4.09 & 46131 & 45631 & 0.005 \\
\hline LDPE & 0.921 & 108 & 2.00 & 0.16 & 85.07 & 14.27 & 0.005 & 0.49 & 46081 & 45581 & 0.005 \\
\hline PP & 0.949 & 170 & 2.50 & 0.18 & 85.41 & 14.37 & 0.005 & 0.04 & 46223 & 45723 & 0.005 \\
\hline PS & 1.040 & $210-260$ & 2.50 & 0.14 & 91.85 & 8.06 & 0.005 & 0.17 & 41672 & 41172 & 0.005 \\
\hline
\end{tabular}

Table 2

HEAVY METALS AND METALLOIDS LEVELS (MG/L) IN THE PPO VERSUS CLASSIC FUELS

\begin{tabular}{|c|c|c|c|c|c|c|c|c|c|c|c|c|}
\hline Fuel type & $\mathrm{Cd}$ & $\mathrm{Pb}$ & $\mathrm{Cr}$ & Mn & $\mathrm{Co}$ & $\mathrm{Ni}$ & $\mathrm{Cu}$ & As & $\mathrm{Se}$ & $\mathrm{Hg}$ & $\mathbf{R b}$ & $\mathrm{Sr}$ \\
\hline $\mathrm{PPO}_{\mathrm{pp} 450}$ & 0.12 & 0.09 & 1.97 & 0.29 & 0.21 & 0.56 & 0.06 & 0.37 & 1.61 & 0.00 & 0.17 & 0.06 \\
\hline $\mathrm{PPO}_{\text {HDPE }} 450^{\circ}$ & 0.34 & 0.53 & 2.49 & 8.11 & 1.39 & 3.83 & 2.31 & 0.17 & 1.72 & 0.00 & 0.01 & 0.72 \\
\hline PPO & 0.05 & 0.06 & 3.11 & 0.01 & 0.07 & 4.56 & 1.75 & 0.35 & 2.40 & 0.00 & 0.21 & 0.05 \\
\hline PPOps450 & 0.07 & 0.07 & 10.0 & 0.37 & 0.16 & 0.02 & 0.27 & 0.30 & 2.12 & 0.00 & 0.22 & 0.15 \\
\hline Diesel $^{* *}$ & $\begin{array}{ll} & 15.0 \\
0 & \\
\end{array}$ & 10.1 & 8.60 & - & - & - & 17.7 & - & - & - & - & - \\
\hline Kerosene** & $\begin{array}{ll} & 13.3 \\
0 & \\
\end{array}$ & 4.10 & 3.30 & - & - & - & 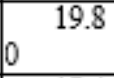 & - & - & - & - & - \\
\hline Gasoline ${ }^{* *}$ & ${ }_{0} 16.8$ & 2.40 & 5.40 & - & - & - & 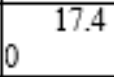 & - & - & 0.77 & - & - \\
\hline
\end{tabular}

${ }^{*} 450=$ the pyrolysis temperature $\left({ }^{\circ} \mathrm{C}\right) ;{ }^{* *}$ results shown by Alpoveta and Osalwe, 2014

Table 3

FUEL PROPERTIES OF THE PPOS RESULTED FROM PYROLYSIS OF PLASTIC MATERIALS, COMPARED WITH THOSE OF CLASSICAL FUELS

\begin{tabular}{|c|c|c|c|c|c|c|c|c|c|}
\hline Fuel type & $\begin{array}{c}\mathbf{N} \\
\text { wt.\% }\end{array}$ & $\begin{array}{c}\mathrm{C} \\
\text { wt. } \%\end{array}$ & $\begin{array}{c}\mathrm{H} \\
\text { wt. } \%\end{array}$ & $\begin{array}{c}\mathrm{S} \\
\text { wt. } \%\end{array}$ & $\begin{array}{c}0 \\
\text { wt. } \%\end{array}$ & $\begin{array}{c}\mathrm{HHV} \\
\mathrm{MJ} / \mathrm{kg}\end{array}$ & $\begin{array}{c}\text { LHV } \\
\mathrm{MJ} / \mathrm{kg}\end{array}$ & $\begin{array}{l}\rho 25^{\circ} \mathrm{C} \\
\mathrm{g} / \mathrm{cm}^{3}\end{array}$ & Colour \\
\hline \multicolumn{10}{|c|}{ Pyrolysis without catalysts } \\
\hline $\mathrm{PPO}_{\text {HDPE } 450}$ & 0.34 & 80.71 & 13.24 & $<\mathrm{LQ}$ & 5.71 & 44.50 & 44.00 & 0.76 & yellow-green \\
\hline $\mathrm{PPO}_{L D P E} 450$ & 0.46 & 78.69 & 12.93 & $<\mathrm{LQ}$ & 7.92 & 44.23 & 43.73 & 0.75 & yellow-green \\
\hline $\mathrm{PPO}_{\mathrm{pp}}^{450}$ & 0.30 & 68.83 & 11.47 & $<\mathrm{LQ}$ & 19.40 & 44.63 & 44.13 & 0.76 & yellow \\
\hline $\mathrm{PPO}_{450}$ & 0.31 & 87.92 & 7.86 & $<\mathrm{LQ}$ & 3.91 & 40.18 & 39.68 & 0.91 & red-brown \\
\hline \multicolumn{10}{|c|}{ Pyrolysis with SBA-15 as catahsts } \\
\hline $\mathrm{PPO}_{\text {HDPE }+\$ \mathrm{SBA}} 15450$ & 0.26 & 82.81 & 11.01 & $<\mathrm{LQ}$ & 5.91 & 46.92 & 46.42 & 0.76 & yellow-green \\
\hline $\mathrm{PPO}_{L D P E}+$ SBA.15 450 & 0.09 & 88.21 & 10.24 & $<\mathrm{LQ}$ & 1.46 & 48.29 & 47.79 & 0.75 & yellow-green \\
\hline $\mathrm{PPOpP}+$ SB.A15 450 & 0.20 & 77.03 & 9.95 & $<\mathrm{LQ}$ & 12.82 & 47.42 & 46.92 & 0.76 & yellow \\
\hline PPOps+sB.A15 450 & 0.21 & 89.81 & 7.23 & $<\mathrm{LQ}$ & 2.75 & 41.60 & 41.10 & 0.91 & red-brown \\
\hline \multicolumn{10}{|c|}{ Pyrohsis with MCM-41 as catalysts } \\
\hline $\mathrm{PPO}_{\text {FDPE }}+\mathrm{MCOM} 411450$ & 0.18 & 81.08 & 10.52 & $<\mathrm{LQ}$ & 8.22 & 45.74 & 45.24 & 0.76 & yellow-green \\
\hline $\mathrm{PPO}_{\text {LDPE }}+\mathrm{MCN} 41450$ & 0.14 & 90.22 & 9.24 & $<\mathrm{LQ}$ & 0.40 & 49.19 & 48.69 & 0.75 & yellow-green \\
\hline $\mathrm{PPOpp}+\mathrm{MCM} 41450$ & 0.21 & 71.14 & 8.68 & $<\mathrm{LQ}$ & 19.97 & 45.59 & 45.09 & 0.76 & yellow \\
\hline $\mathrm{PPO}_{\mathrm{PS}}+\mathrm{MCM} 41450$ & 0.14 & 88.13 & 7.26 & $<\mathrm{LQ}$ & 4.47 & 41.16 & 40.66 & 0.91 & red-brown \\
\hline \multicolumn{10}{|c|}{ Classical fuels } \\
\hline Diesel $^{8}$ & 0.75 & 83.46 & 12.13 & 0.01 & 3.65 & 46.03 & 43.37 & 0.78 & yellow-green \\
\hline Gasoline* & 0.31 & 85.16 & 11.09 & 0.01 & 3.43 & 45.56 & 43.90 & 0.81 & yellow-green \\
\hline $\mathrm{HFO}^{8}$ & 0.64 & 86.93 & 8.61 & 0.77 & 3.05 & 42.60 & 40.71 & 0.80 & black \\
\hline LFO $^{*}$ & 0.59 & 84.00 & 10.33 & 0.01 & 5.07 & 40.96 & 38.69 & 0.84 & yellow \\
\hline & & & & & & & & & \\
\hline
\end{tabular}

** Investigations made under ISO17025:2005; $\mathrm{L}_{\mathrm{Q}}=$ quantification limit for sulphur $\mathrm{S}<10 \mathrm{ppm}$; HFO - heavy fuel oil; LFO - light fuel oil.

Evaluation of the plastic based pyrolysis products

The main objective of the present study was to found a reliable solution to eliminate plastic wastes pollution through their energy recovery. Valorisation refers to pyrolysis benefits, such as oil and gaseous products, PPO and PPG. The amount, and also the type of valuable products are important issues. As observed from Fig. 4, the amount of wax residue (PPW) decreased in the catalytic pyrolysis experiments.

Wastes rich in HDPE, LDPE and PP showed affinity in producing PPGs following pyrolysis processes, in absence/presence of catalysts. On the contrary, in the case of PS, PPO level was higher than $50 \%$, the catalysts used in the 
catalytic formulations without giving too much intake to the PPG. In conclusion, the MCM-41 and SBA-15 catalysts do not favour production of PPO or PPG in a proportion that is required in a certain context / process.
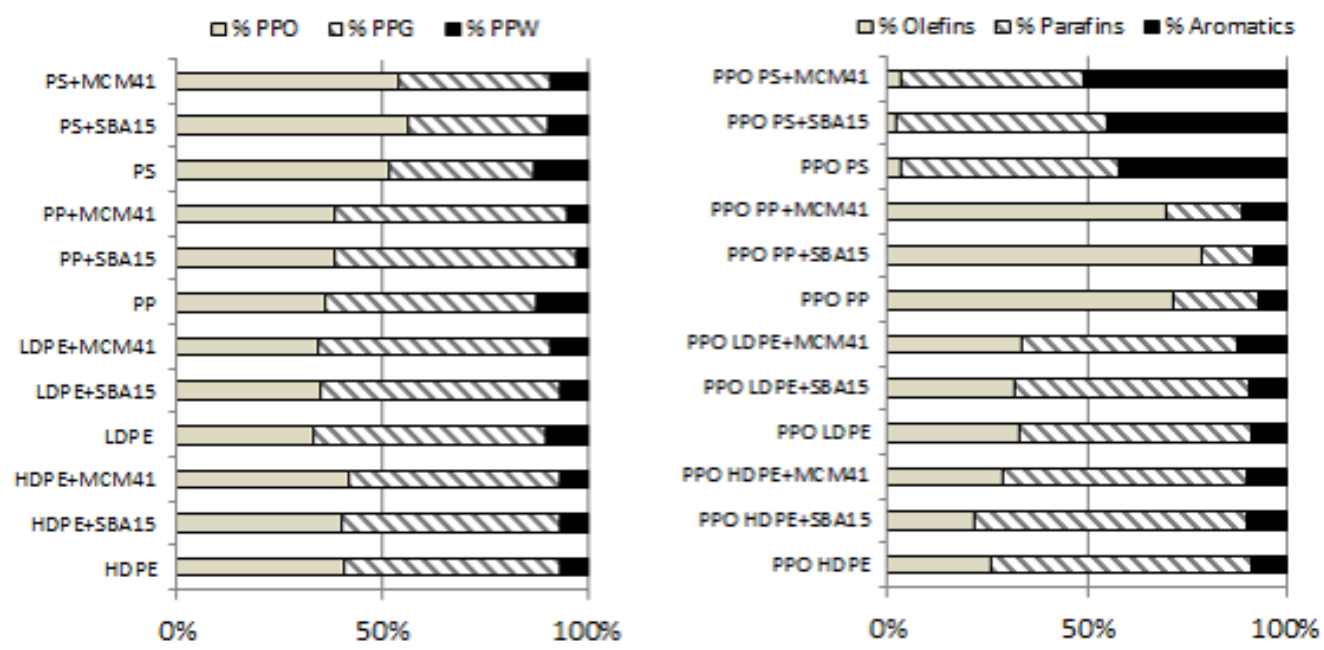

Fig. 4. Characterisation of the plastic waste pyrolysis products: a) percentages of PPO, PPG and PPW resulted from plastic pyrolysis (left graph); b) the content in aromatics, paraffin and olefins of the PPO's (right graph)

Some novel aspects were observed on PPO samples. The increase of the PPOs calorific value was correlated to the higher level of aromatic hydrocarbons after catalytic experiments, as observed in Fig. 4. The PPOPS450 was the only obtained fuel oil containing tertiary-butyl ether (ETBE), commonly used as a gasoline additive. ETBE offers some benefits. In contrast to ethanol, ETBE does not determine evaporation of gasoline, which is one of the smog causes, and does not absorb moisture from the atmosphere.

The pyrolysis process of PP, PS, HDPE and LDPE, polymers with similar structures, generated a wide variety of hydrocarbons, alkanes, alkenes, aromatics, permanently gases in the PPGs, together with their chemical composition and physical properties. Table 4 shows the complex composition of a PPG, providing a robust gas, a feasible alternative to biogas, geothermal gas and natural gas.

The results showed that both mesoporous silica materials, SBA-15 and MCM-41 contributed to changes of the gas composition, with resulted aromatic hydrocarbons, helping to increase the calorific value of the final product. Also, an increase in hydrogen concentrations left unreacted by breaking the polymer chain was noticed. The decreased levels of $\mathrm{CO}$ and $\mathrm{CO}_{2}$ of PPG resulted from catalytic pyrolysis can be attributed to the structure of the two types of catalysts. PPGs did not generate hydrogen sulphide, which is a highly toxic gas and specific to other "competing" combustible gases, from the gaseous fuels market, whether classic or renewable - natural gas or biogas, all of them having variable content of $\mathrm{H}_{2} \mathrm{~S}$, from several hundred up to several thousand ppm [29]. High content of $\mathrm{H}_{2} \mathrm{~S}$ in any type of fuel gas leads to the degradation/corrosion of transport installations. Also, combustion of fuels with high content of $\mathrm{H}_{2} \mathrm{~S}$ generates a negative environmental impact and an obvious degradation of the quality of life. As shown in Table 4, the polymers PE, PP and PS undergo a first crackdown on noncatalytic PPGs to ethylene, propylene and styrene.

In a second stage, their concentration in catalytic PPGs dropped without exception, in hydrocarbons such as alkanes, alkenes, recombined in the aromatics, but also in free hydrogen. The effect of the pyrolysis temperature, $450{ }^{\circ} \mathrm{C}$, was not the only one that contributes to the formation of hydrocarbons in PPGs, the diversity being even greater after the application of SMMS/catalysts and its positioning in the reactor. Between the two catalysts, SBA15 determined a higher impact on the increase in energy value of PPGs, regardless of polymer. An improvement in the energy quality compared to non-catalytic PPGs was observed in the case of $\mathrm{PPG}_{\mathrm{HDPE} 450+\mathrm{SBA} 15}, \mathrm{PPG}_{\mathrm{PP} 450+\mathrm{SBA} 15}$ and $\mathrm{PPG}_{\mathrm{PS} 450+\mathrm{SBA} 15}$. The same catalyst, SBA15, was also "responsible" in PPOs case for improving the energy quality, which is a consequence of the acid site structure of this type of catalyst. Table 4 also illustrates a gaseous matrix, both classical and alternative, "competitors" of the new alternative PPG gas developed in this study. PPG had a wider range of hydrocarbons resulting in a higher energy level compared to the other fuels, which is recommended for most energy-intensive uses, from high-energy consumers such as the cement industry to the mural power plants assigned to the local community mayors. The differences in energy value are net in favour of newly developed PPGs, whether catalytic or non-catalytic. It can be observed how natural gas abounds especially in methane, as well as biogas from sludge and geothermal gas.

The mesoporous silica manifested strong cracking activities in the pyrolysis, as evidenced by the significantly reduced yields of liquid and wax product and the improved gas yields in comparison to the non-catalytic thermal decomposition. Generally, the microporous catalysts present higher gas yields and lower oil and wax yields compared with the mesoporous materials, probably due to their higher acidic nature, resulting severe secondary cracking of the primary pyrolytic intermediate species. Furthermore, the size selectivity of the catalysts could also influence the high gas yield associated with the microporous catalysts. 


\section{Conclusions}

PS, PP, HDPE and LDPE plastic polymers were subjected to pyrolysis in a fixed bed reactor under catalysis of MCM-41 and SBA-15 mesoporous silica, or no catalysis. The composition of the resulted PPO and PPG showed increased yield of

Table 4

CHEMICAL COMPOSITIONS AND PHYSICAL PROPERTIES OF PLASTIC PYROLYSIS RESULTED FUEL GASES

\begin{tabular}{|c|c|c|c|c|c|c|c|c|c|c|c|c|c|c|c|c|}
\hline \multirow[b]{2}{*}{$\begin{array}{l}\text { Composition } \\
\text { / Properties }\end{array}$} & \multicolumn{4}{|c|}{ Pyrolysis without catalysts } & \multicolumn{4}{|c|}{ Pyrolysis nith SBA-15 as catalysts } & \multicolumn{4}{|c|}{ Pyrolysis nith MCM-41 as catalysts } & \multicolumn{4}{|c|}{ Classical fuels } \\
\hline & 总亮 & 总 & 总咅 & 总 $\frac{a}{4}$ & 总 & 总 & 总 & 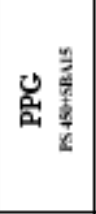 & 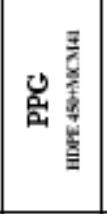 & 总 & 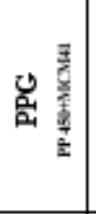 & 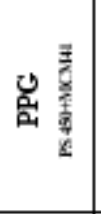 & 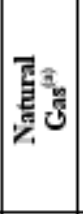 & 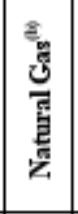 & 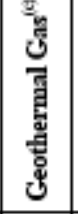 & 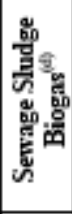 \\
\hline $\mathrm{Cl}(\mathrm{Vol} \%)$ & 3.93 & 4.26 & 4.94 & 0.30 & 2.16 & 3.96 & 3.38 & 0.24 & 1.36 & 1.67 & 4.11 & 1.11 & 91.85 & 99.38 & 80.79 & 64.22 \\
\hline $\mathrm{C} 2(\mathrm{Vol} \%)$ & 8.83 & 11.07 & 2.00 & 5.34 & 4.84 & 4.70 & 1.74 & 4.48 & 3.12 & 4.33 & 1.84 & 3.37 & 2.96 & 0.16 & 0.77 & 0.03 \\
\hline Ethylene (Vol\%) & 5.17 & 4.23 & 18.68 & 2.06 & 6.19 & 9.62 & 15.32 & 2.34 & 5.59 & 6.40 & 14.73 & 3.09 & 0.00 & 0.00 & 0.00 & 0.00 \\
\hline $\mathrm{C} 3(\mathrm{Vol} \%)$ & 19.54 & 19.32 & 4.90 & 1.75 & 5.87 & 24.50 & 4.15 & 2.00 & 6.82 & 14.52 & 4.11 & 1.99 & 0.80 & 0.05 & 0.14 & 0.01 \\
\hline Propylene (Vol\%) & 20.03 & 17.20 & 59.61 & 3.73 & 35.49 & 27.03 & 51.95 & 5.54 & 39.47 & 23.53 & 48.73 & 4.48 & 0.00 & 0.00 & 0.00 & 0.00 \\
\hline $\mathrm{i}-\mathrm{C} 4(\mathrm{Vol} \%)$ & 0.15 & 0.23 & 0.44 & 0.10 & 0.15 & 0.54 & 0.34 & 0.12 & 0.20 & 1.61 & 0.54 & 0.15 & 0.25 & 0.01 & 0.02 & 0.01 \\
\hline $\mathrm{n}-\mathrm{C} 4(\mathrm{Vol} \%)$ & 12.17 & 13.97 & 1.89 & 1.48 & 1.49 & 5.38 & 2.12 & 1.40 & 1.67 & 1.79 & 1.78 & 1.09 & 0.25 & 0.013 & 0.02 & 0.01 \\
\hline neo-C5 $(\mathrm{Vol} \%)$ & 10.94 & 13.79 & 0.00 & 1.66 & 1.99 & 0.41 & 0.11 & 1.09 & 2.27 & 1.73 & 0.14 & 0.99 & 0.01 & 0.01 & 0.01 & 0.01 \\
\hline i-C5 $(\mathrm{Vol} \%)$ & 0.24 & 0.00 & 0.98 & 2.91 & 0.07 & 1.27 & 1.11 & 2.20 & 0.16 & 3.20 & 0.99 & 1.99 & 0.13 & 0.01 & 0.01 & 0.01 \\
\hline $\mathrm{n}-\mathrm{C}$ & 3.74 & 0.24 & 0.24 & 5.48 & 0.66 & 1.59 & 0.78 & 4.44 & 0.80 & 3.33 & 0.56 & 3.33 & 0.06 & 0.01 & 0.01 & 0.01 \\
\hline $\mathrm{n}-\mathrm{C} 6 \mathrm{C}$ & 1.42 & 1.26 & 0.69 & 4.82 & 11.66 & 4.75 & 1.25 & 4.47 & 9.76 & 6.53 & 2.08 & 2.09 & 0.06 & 0.03 & 0.01 & 0.01 \\
\hline 2.3-Dimethy & 4.80 & 0.00 & 0.00 & 0.00 & 3.97 & 0.13 & 0.98 & 0.19 & 4.61 & 1.32 & 1.09 & 0.11 & 0.00 & 0.00 & 0.00 & 0.00 \\
\hline 2-Methylhexane (Vol\%) & 0.00 & 0.00 & 0.00 & 0.03 & 6.93 & 0.01 & 0.77 & 0.19 & 4.68 & 1.42 & 0.67 & 0.10 & 0.00 & 0.00 & 0.00 & 0.00 \\
\hline 3-Ethylpentane (Vol\%) & 0.00 & 0.00 & 0.00 & 0.06 & 0.63 & 0.01 & 0.26 & 0.21 & 0.59 & 1.38 & 0.19 & 0.29 & 0.00 & 0.00 & 0.00 & 0.00 \\
\hline 3-Methylhexane (Vol\%) & 0.00 & 0.00 & 0.00 & 0.11 & 2.29 & 0.01 & 0.11 & 0.11 & 2.31 & 0.97 & 0.10 & 0.10 & 0.00 & 0.00 & 0.00 & 0.00 \\
\hline 2.2.3-Trimethylbutane (Vol\%) & 0.00 & 0.00 & 0.00 & 0.03 & 0.38 & 0.01 & 0.25 & 0.04 & 0.40 & 0.83 & 0.25 & 0.04 & 0.00 & 0.00 & 0.00 & 0.00 \\
\hline Methyl cycloherane (Vol\%) & 2.04 & 0.00 & 0.00 & 0.01 & 0.00 & 0.03 & 0.69 & 0.01 & 0.00 & 0.61 & 0.60 & 0.31 & 0.00 & 0.00 & 0.00 & 0.00 \\
\hline $\mathrm{n}-\mathrm{C} 7(\mathrm{Vol} \%)$ & 0.00 & 0.00 & 0.00 & 0.16 & 1.39 & 0.04 & 1.03 & 0.12 & 1.47 & 0.14 & 0.98 & 0.11 & 0.00 & 0.00 & 0.00 & 0.00 \\
\hline Benzene (Vol\%) & 0.00 & 0.00 & 0.00 & 7.01 & 3.06 & 1.58 & 1.11 & 10.07 & 1.91 & 2.91 & 1.10 & 10.52 & 0.00 & 0.00 & 0.00 & 0.00 \\
\hline $\mathrm{i}-\mathrm{C} 8(\mathrm{Vol} \%)$ & 0.00 & 0.00 & 0.00 & 0.97 & 1.16 & 1.39 & 0.80 & 1.15 & 1.24 & 1.61 & 0.90 & 0.98 & 0.00 & 0.00 & 0.00 & 0.00 \\
\hline & 0.00 & 0.00 & 0.00 & 0.80 & 0.65 & 1.48 & 0.80 & 1.09 & 0.68 & 1.42 & 1.09 & 1.70 & 0.00 & 0.00 & 0.00 & 0.00 \\
\hline Tolue & 0.00 & 0.00 & 0.00 & 3.84 & 1.30 & 3.13 & 1.00 & 5.49 & 1.36 & 3.50 & 1.08 & 6.98 & 0.00 & 0.00 & 0.00 & 0.00 \\
\hline Styren: & 0.00 & 0.00 & 0.00 & 53.06 & 0.00 & 0.00 & 0.00 & 49.89 & 0.00 & 0.00 & 0.00 & 49.91 & 0.00 & 0.00 & 0.00 & 0.00 \\
\hline $\mathrm{H}_{2} \mathrm{C}$ & 2.19 & 1.97 & 3.87 & 0.78 & 7.62 & 4.75 & 8.64 & 2.02 & 8.15 & 13.94 & 11.05 & 3.99 & 0.00 & 0.00 & 0.00 & 0.00 \\
\hline $\mathrm{COC}$ & 0.65 & 3.41 & 1.36 & 2.08 & 0.01 & 2.70 & 1.00 & 0.11 & 0.56 & 0.26 & 1.00 & 0.19 & 0.00 & 0.00 & 0.00 & 0.00 \\
\hline $\mathrm{CO}_{2}(\mathrm{Vol} \%)$ & 4.16 & 0.64 & 0.40 & 1.43 & 0.01 & 0.95 & 0.30 & 0.98 & 0.80 & 1.03 & 0.30 & 1.00 & 0.27 & 0.11 & 0.34 & 35.4 \\
\hline $\mathrm{H}_{2} \mathrm{~S}(\mathrm{Vol} \%)$ & 0.00 & 0.00 & 0.00 & 0.00 & 0.00 & 0.00 & 0.00 & 0.00 & 0.00 & 0.00 & 0.00 & 0.00 & 0.01 & 0.01 & 0.02 & 0.01 \\
\hline & 0.00 & 0.00 & 0.00 & 0.00 & 0.00 & 0.00 & 0.00 & 0.00 & 0.00 & 0.00 & 0.00 & 0.00 & 0.01 & 0.01 & 0.04 & 0.05 \\
\hline $\mathrm{HHV}$ & 99.84 & 99.47 & 82.92 & 92.80 & 124.82 & 100.71 & 91.65 & 98.58 & 119.71 & 110.77 & 90.37 & 95.06 & 40.39 & 39.94 & 33.55 & 25.72 \\
\hline $\mathrm{NHV}\left(\mathrm{MI} / \mathrm{m}^{3}\right) 0^{\circ} \mathrm{C}$ & 92.70 & 92.42 & 77.23 & 87.36 & 115.88 & 93.44 & 85.31 & 92.92 & 111.14 & 102.76 & 84.06 & 89.76 & 36.39 & 35.91 & 30.17 & 23.12 \\
\hline $\mathrm{d}\left(\mathrm{kg} / \mathrm{m}^{3}\right) 0^{\circ} \mathrm{C}$ & 1.67 & 1.66 & 1.40 & 3.02 & 2.08 & 1.69 & 1.58 & 3.03 & 2.02 & 1.92 & 1.57 & 3.00 & 0.78 & 0.72 & 0.82 & 1.16 \\
\hline$\rho\left(\mathrm{kg} / \mathrm{m}^{3}\right) 0^{\circ} \mathrm{C}$ & 2.16 & 2.14 & 1.81 & 3.91 & 2.68 & 2.19 & 2.04 & 3.92 & 2.61 & 2.48 & 2.03 & 3.88 & 0.66 & 0.62 & 0.63 & 0.90 \\
\hline Wobbe No. $\left(\mathrm{MI} / \mathrm{m}^{3}\right) 0^{\circ} \mathrm{C}$ & 77.33 & 77.31 & 70.08 & 53.38 & 86.61 & 77.41 & 72.99 & 56.60 & 84.30 & 80.02 & 72.07 & 54.88 & 51.99 & 53.39 & 42.15 & 27.10 \\
\hline $\mathrm{EF}(\mathrm{t} T \mathrm{~T})$ & 69.44 & 69.62 & 71.75 & 132.75 & 71.58 & 70.47 & 73.47 & 127.12 & 71.90 & 73.73 & 74.20 & 130.32 & 55.83 & 54.92 & 55.21 & 85.01 \\
\hline HHV $\left(\mathrm{MI} / \mathrm{m}^{2}\right) 15^{\circ} \mathrm{C}$ & 106.46 & 106.00 & 80.74 & 163.94 & 84.49 & 105.92 & 88.80 & 163.96 & 115.57 & 112.51 & 87.52 & 159.75 & 38.22 & 37.79 & 31.74 & 24.32 \\
\hline $\mathrm{NHV}\left(\mathrm{MI} / \mathrm{m}^{2}\right) 15^{\circ} \mathrm{C}$ & 99.17 & 98.77 & 75.83 & 155.22 & 78.50 & 98.66 & 83.24 & 155.33 & 107.88 & 104.79 & 81.96 & 151.50 & 34.47 & 34.02 & 28.59 & 21.90 \\
\hline $\mathrm{d}\left(\mathrm{kg}^{2} \mathrm{~m}^{2}\right) 15^{\circ} \mathrm{C}$ & 2.05 & 2.04 & 1.74 & 3.08 & 1.61 & 2.02 & 1.88 & 3.08 & 2.27 & 2.18 & 1.86 & 3.03 & 0.744 & 0.685 & 0.78 & 1.10 \\
\hline & 2.52 & 2.50 & 2.13 & 3.78 & 1.97 & 2.47 & 2.30 & 3.78 & 2.78 & 2.67 & 2.28 & 3.72 & 0.645 & 0.588 & 0.63 & 0.90 \\
\hline Wobbe No. $\left(\mathrm{MI} / \mathrm{m}^{2}\right) 15^{\circ} \mathrm{C}$ & 74.28 & 74.25 & 61.18 & 93.38 & 66.68 & 74.56 & 64.79 & 93.37 & 76.71 & 76.25 & 64.23 & 91.75 & 49.19 & 50.53 & 39.88 & 25.64 \\
\hline
\end{tabular}

aromatic compounds with a further rise in aromatic content with increase of temperature. The mainly hydrocarbons in the oils were in the range of C6-C21 with their derivatives. The formed gases were olefins, paraffin and aromatics.

Lower energy consumption was obtained by using the catalysts, the reduction being of $30 \%$. The use of catalysts in a sandwich metallic mesh system (SMMS) led to saving of catalysts for other experiments, yielding up to $50 \%$.

The level of waste resulting from the plastics pyrolysis was up to $10 \%$; as applicability, the pyrolysis waste (PPW) can be used in specific building materials or for the development of nanomaterials.

The emissions levels of nitric and sulphur oxides after combustion of PPO's and PPG's were very low, unlike classic liquid and gaseous fuels; no chlorine emissions were obtained after combustion of PPO's and PPG's.

According to the data obtained in this study, the fuels developed by using plastic wastes in pyrolytic processes can be included in the family of alternative fuels. 
Acknowledgments: The work has been funded by the Operational Programme Human Capital of the Ministry of European Funds through the Financial Agreement 51668/09.07.2019, SMIS code 124705, supported by the Romanian Ministry of Scientific Research and Innovation, under PN-III-CERC-COCI-2018 Program, Project no. 159CI/2018 “Plastic wastes as vector for energy-ENERGPLAS” and NUCLEU Program, Project PN 19110301 ,,Studies on the obtaining and improvement of the acido-basic properties of the nanoporous catalytic materials for application in valorisation of wastes".

\section{References}

1.*** World's first Ocean plastics-cleaning machine set to tackle Great Pacific Garbage Patch. https://www.independent.co.uk (2018) (accessed on 11 January 2019).

2.SINGH, N., HUI, D., SINGH, R., AHUJA, I.P.S., FEO, L., FRATERNALI, F., Compos. Part B, 115, 2017, p. 409.

3.ASCHILEAN, I., RASOI, G., RABOACA, M.S., FILOTE, C., CULCER, M., Energies, 11, 2018, p. 1.

4.FELSEGHI, R.A., Progress of cryogenics and Isotopes Separation, 18, 2015, p. 53.

5.SOGANCIOGLU, M., YEL, E., AHMETLI, G., Energy Proced., 118, 2017, p. 189.

6.DAS, P., TIWARI, P., Resour. Conserv. Recy., 128, 2018, p. 69.

7.AL-SALEM, S.M., ANTELAVA, A., CONSTANTINOU, A., MANOS, G., DUTTA, A., J. Environ. Manage., 197, 2017 , p. 177.

8.FELSEGHI, R.A., SOIMOSAN, T.M., MEGYESI, E., SGEM2014 Conference Proceedings, 4, no. 1, 2014, p. 377

9.CHIWARA, B., MAKHURA, E., DANHA, G., BHERO, S., MUZENDA, E., AGACHI, P., Proceedings Sardinia 2017/Sixteenth International Waste Management and Landfill Symposium/ 2 - 6 October, 2017, S. Margherita di Pula, Cagliari, Italy.

10.LI, K., LEE, S.W., YUAN, G., LEI, J., LIN, S., WEERACHANCHAI, P., YANG, Y., WANG, J.Y., Energies, 9, no. 6, 2016 , p. 431.

11.KUMAR, S., SINGH, R.K., Braz. J. Chem. Eng., 28, no. 4, 2011, p. 659.

12.LEE, K.H., InTech., 2012, p. 175.

13.BAGRI, R., WILLIAMS, P.T., J. Anal. Appl. Pyrolysis, 63, no.1, 2002, p. 29.

14.SONAWANE, Y.B., SHINDIKAR, M., KHALADKAR, M., Int. Res. J. Enviro. Sci., 4, no. 7, 2015, p. 24.

15.CONSTANTINESCU, M., BUCURA, F., IONETE, R.E., ZAHARIOIU, A., CIUCURE, C., OANCEA, S., SGEM2017 Vienna GREEN Conference Proceeding, 17, no. 43, 2017, p. 767.

16.CONSTANTINESCU, M., OANCEA, S., BUCURA, F., CIUCURE, C., IONETE, R.E., J. Renew. Sustain. Energy, 10, no. 5, 2018 , article no. 053106. 17.NICULESCU, V., ENE, R., IORDACHE, I., PARVULESCU, V., Progress Cryogenics Isotope Separation, 15, no. 1, 2012 , p. 97.

18.NICULESCU, V., ALDEA, N., REDNIC, V., PARVULESCU, V., Anal. Lett., 52, no.1, 2018, p. 1.

19.MIRICIOIU, M.G., IACOB, C., NECHIFOR, G., NICULESCU, V., Front. Chem., 7, 2019, article no. 332, doi: 10.3389/fchem.2019.00332

20.JUNG, M.R., HORGEN, F.D., ORSKI, S.V., RODRIGUEZ, V., BEERS, K., BALAZS, G.H., JONES, T.T., WORK, T.M., BRIGNAC, K.C., ROYER, S.J., HYRENBACH, K.D., JENSEN, B.A., LYNCH, J.M., Mar. Pollut. Bull., 127, 2018, p. 704.

21.ZAHARIA, A., RADU, A.L., IANCU, S., FLOREA, A.M., SANDU, T., MINCA, I., FRUTH-OPRISAN, V., TEODORESCU, M., SARBU, A., IORDACHE, T.V., RSC Adv., 8, 2018, p. 17635.

22.FLOREA, A.M., IORDACHE, T.V., ZAHARIA, A., GEORGESCU, B., VOICU, A.E., TSYNTSARSKI, B., HUBCA, G., SARBU, A., Mat. Plast., 54, no. 3, 2017, p. 495.

23.GAVRILA (FLOREA), A.M., IORDACHE, T.V., SANDU, T., ZAHARIA, A., RADU, A.L., BRANGER, C., BRISSET, H., STOICA, E.B., APOSTOL, S., SARBU, A., Mat. Plast., 56, no. 2, 2019, p. 315.

24.CONSTANTINESCU, M., BUCURA, F., IONETE, R.E., NICULESCU, V.C., IONETE, I.E., ZAHARIOIU, A., OANCEA, S., MIRICIOIU, M.G., Mat. Plast., 56, no. 1, 2019, p. 41.

25.*** ASTM D240-17. Standard Test Method for Heat of Combustion of Liquid Hydrocarbon Fuels by Bomb Calorimeter, 2017.

26.STEGARUS, D., NICULESCU, V., GEORGESCU, C., IANCU, R., LENGYEL, E., TITA, O., Rev. Roum. Chim., 60, no. 5-6, 2015 , p. 507.

27.***ISO 6976 Natural gas - Calculation of calorific values, density, relative density and Wobbe indices from composition, 2016.

28.MIRICIOIU, M.G., BUCURA, F., ZAHARIOIU, A., CONSTANTINESCU, M., NICULESCU, V., SGEM2017 Conference Proceeding, 17, no. 42, 2017, p. 3.

29.BUCURA, F., IONETE, R.E., MARIN, F., MIRICIOIU, M., SAROS, G., ZAHARIOIU, A., CONSTANTINESCU, M., Progress of Cryogenics and Isotope Separation, 21, no. 1, 2018, p. 97.

30.XUE, Y., KELKAR, A., BAI, X., Fuel, 166, 2016, p. 227.

31.CONTAT-RODRIGO, L., RIBES-GREUS, A., IMRIE, C.T., J. Appl. Polym. Sci., 86, 2002, p. 764.

32.TCHOUNWOU, P.B., YEDJOU, C.G., PATLOLLA, A.K., SUTTON, D.J., Molecular, Clinical and Environmental Toxicology, 101, 2012 , p. 133. 33.AKPOVETA, O.V., OSAKWE, S.A., IOSR J. Appl. Chem., 7, no. 6, 2014, p. 1.

Manuscript received: 11.11 .2019 